\title{
Gabriel García Márquez, History and the Labyrinth of Literature
}

\author{
Rodica Grigore ${ }^{1}$
}

Gabriel García Márquez's novel centered on Simón Bolívar, The General in His Labyrinth (El general en su laberinto, 1989) provoked mixed reactions from the literary critics. Some of them praised another masterpiece, whereas the others accused the Colombian author of creating a disrespectful portrait one of Latin America's most important historical and symbolic figures The novel combines historical data and fiction in order to humanize the character of the Liberator and to destroy his nearly mythological image while at the same time examining the implications of previous literary discourse on the contemporary Latin American novel. Moreover García Márquez finds an original means of establishing a profound relationship between the magical realist aesthetics he used in One Hundred Years of Solitude and this particular form of pseudohistorical narrative that succeeds in expressing the humanity of its protagonist. [Article copies available for a fee from The Transformative Studies Institute.E-mail address: journal@transformativestudies.org Website: http://www.transformativestudies.org (C2020 by The Transformative Studies Institute. All rights reserved.]

\footnotetext{
${ }^{1}$ Rodica Grigore, Ph.D., is senior lecturer in Comparative Literature at "Lucian Blaga" University of Sibiu, Romania. She is the author of several critical studies: Despre cărţi şi alţi demoni [Of Books and Other Demons, 2002], Retorica măştilor în proza interbelică românească [The Rhetoric of Masks in Romanian Modern Fiction, 2005], Lecturi in labirint [Readings in the Labyrinth, 2007], Măşti, caligrafie, literatură [Masks, Calligraphy, Literature, 2011], In oglinda literaturii [In the Mirror of Literature, 2011], Meridianele prozei [Fiction's Meridians, 2013], Pretextele textului [The Pretexts of the Text, 2014], Realismul magic în proza latino-americană a secolului XX. [Magical Realism in Latin-American Fiction of the 20 $0^{\text {th }}$ Century, 2015], Călătorii în bibliotecă. Eseuri [Journeys in the Library. Essays, 2016], Cărți, vise și identități în mișcare. Eseuri despre literatura contemporană [Books, Dreams and Changing Identities. Essays on the Contemporary Literature, 2018]. She has also translated into Romanian the essays of Octavio Paz, Children of the Mire, (2003/2017) and the poems of the Colombian writer Manuel Cortés Castañeda, Oglinda celuilalt [The Mirrored Other, 2006]. Between 2005 and 2012 she has been coordinating the anthology of The International Theatre Festival of Sibiu. She has published numerous essays and critical studies especially on modern literature in Romanian literary journals: "Observator Cultural", "Euphorion", "Viaţa Românească" etc. She is also known as a translator from English and Spanish. Address correspondence to: Rodica Grigore; e-mail: rodica.grigore@gmail.com.
} 
KEYWORDS: History, Fiction, Latin American Novel, Narrative Strategies, Magical Realism.

\section{LITERARY DISCOURSE AND THE TRUTH OF HISTORY}

Simón Bolívar (1783 - 1830) was the leading figure in the movement from Spanish domination between 1810 and 1826 and spread over the entire continent. A brave general and an astute politician, he became the president of The Federative Republic of "Gran Colombia" (including present-day Venezuela, Panama, Colombia and Ecuador) and Peru, but he resigned in 1830 and attempted to leave for Europe. Nevertheless, he was unable to reach to the Old World, and "El Libertador" (as he was proclaimed in 1813 at the National Congress in Venezuela) died alone and in poverty, nearly forgotten by the people to whom he dedicated his life's efforts.

Beginning with these historical facts as well as a project abandoned by his friend, Álvaro Mutis, Gabriel García Márquez began his own book about The Liberator. The text appeared in 1989 as The General in His Labyrinth (El general en su laberinto), sparking debate and controversy all over Latin America and beyond. On the one hand, the Colombian Nobel laureate's admirers praised the publication of a new masterpiece. Conversely his critics and some supporters of Bolívar's vision of unifying South America into a single state accused the author of having shown contempt for one of the most prominent symbols of Latin America. They criticized author's attitude and derided his description of Bolívar as a believable literary character rather than a mythical figure. Nevertheless, García Márquez's detractors seem to have forgotten that The General in His Labyrinth, in spite of the years of research undertaken by the author, is above and beyond all else a novel; in other words, a text in which fiction prevails.

García Márquez did not compose a history of Bolívar because he was convinced as are many contemporary authors that history is largely fictitious, from antiquity to the present; and this particularly so when major figures are mythologized by nationalistic historians. García Márquez sought to use historical reality as a point of departure, providing the reader with historical data by way of official documents, thereafter delving into fictional historiography as a means of creating a work of fiction punctuated by historical details. He similarly used intertextual and metatextual strategies in underpinning his points, at times approaching the "historiographic metafiction" as described by Linda Hutcheon in her studies on postmodern poetics. As a "fictionalized account of the last 